\title{
Investor Decision in Estimating the Effect of Earning Persistence, Financial Leverage, Foreign Ownership Toward Company Reputation and Company Value
}

\author{
Robert Jao ${ }^{1}$, Djabir Hamzah ${ }^{2}$, Abdul Rakhman Laba ${ }^{2} \&$ Mediaty $^{2}$ \\ ${ }^{1}$ Faculty of Economics and Business, Atma Jaya Makassar University, Makassar, Indonesia \\ ${ }^{2}$ Faculty of Economics and Business, Hasanuddin University, Makassar, Indonesia \\ Correspondence: Robert Jao, Faculty of Economics and Business, Atma Jaya Makassar University, Makassar, \\ Indonesia. E-mail: jao_robert@hotmail.com
}

Received: April 9, 2020

doi:10.5430/ijfr.v11n4p453
Accepted: May 27, 2020

Online Published: July 8, 2020

URL: https://doi.org/10.5430/ijfr.v11n4p453

\begin{abstract}
Understanding company effort on managing corporate reputation and corporate value are challenging tasks among investors. This paper provides an estimated relationship of earning persistence, financial leverage, and foreign ownership on corporate reputation and corporate value on non-financial companies listed in Indonesian Stock Exchange. Data are collected from a five-year observation period, ranging 2014 to 2018 . A Non probability sampling technique is purposively used to determine the data quality. The collected data are analyzed and processed using SEM method. This study provides a qualitative result showing the relationship among the variables. The financial leverage has no significant effect on company value. In addition, financial leverage also has no significant impact on company reputation compared to foreign ownership toward company reputation. Earning persistence has significantly affected the company value followed by income variability with equal effect toward corporate reputation. Future study can add additional independent variables such as free cash flow and growth opportunities to expand this study.
\end{abstract}

Keywords: profit persistence, financial leverage, foreign ownership of company reputation, company value

\section{Introduction}

Investors today need to make investment decisions in the capital market based on facts, data, and financial analysis that is appropriate with a rational approach to determine the results of their investments. Investors will consider several aspects such as financial performance, operational performance, macro and micro conditions, market movements and sentiment, and many more (Erasputranto and Hermawan, 2015). If investors focus more on using tangible assets to evaluate business success, investors now need to pay attention to intangible assets. Kamasak (2017) states that intangible assets have a greater contribution to the company's market performance than tangible assets.

Along with financial liberalization, many countries continue to be open to foreign investors. It is undeniable that the presence of foreign investors can have a positive impact. Chau and Gray (2010) examined the effect of ownership on the performance of foreign and domestic companies that are in groups and independent. The results state that there are significant differences in performance monitored by foreign companies compared to domestic companies. Companies that are monitored by foreigners have better performance. A possible reason is that foreign institutions choose companies that are related to the group and have a better level of transparency. In addition, they have better monitoring capabilities than domestic ones.

The scope of Indonesia's investment business in the stock market circulation began to grow rapidly. That can be seen from the growth of the company's quantity and market capitalization on the Indonesia Stock Exchange (IDX). The investment business is being favored by the business community, especially by investors. That's because the funds allocated are considered to bring benefits in the future. From an investment point of view, investors who allocate a portion of their personal assets to increase profits are categorized as investors who choose to invest in financial assets by buying financial instruments such as stocks, bonds, warrants, or mutual funds (Susilo, 2009).

Profit persistence arises when a company is able to improve its performance to create good quality earnings information. With such conditions, investors will be interested in responding to stock movements, which are still 
spinning in the stock market. Notification of profits made by the company will affect the market reaction, the reaction can be in the form of changes in trading volume or changes in stock prices.

The quality of earnings is related to earnings information reported by the company, which can influence investors' decisions when the information is related to earnings where the profit is the net income mentioned in the income statement and the company's ability in creating these profits as predictors of future earnings. Companies with a good overall reputation have valuable assets (Ponzi et al., 2011), important assets (Acharya and Sabri Öncü, 2014). This has become a critical resource because it has the potential for value creation and because its intangible nature makes replication by competing companies more difficult (Adams et al., 2012).

But, as Ginesti et al., (2018) put it, a company's reputation 'must have value for investors because it generates financial returns for the company'. The company's reputation contributes to the value of the company, but they fail to identify 'methods for evaluating and measuring, in dollars, the reputation of each company'.

The company's reputation, as many people already believe, is real, now, and is often a huge asset. Their presence is quite large in the UK and US where they rank among the most important value repositories for listed companies. On January 1, 2012 they contributed almost $26 \%$ of the total market capitalization of the S \& P500, US \$ 3,190 billion of shareholder value. At the same time, they gave US \$ 770 billion in FTSE100 and US \$ 67 billion in FTSE250.

The contribution of reputation, the proportion of a company's market capitalization that is associated with its reputation, varies by company size and is not surprising given the human nature and tendency to generalize, often higher for large companies. In rough terms, it will be seen that even the most difficult-nosed investors conclude the 'level of success' of the measure and who may be prepared to submit a number of judgments to the reputation and pre-formed impressions based on reputation.

One of the missing assets is the company's reputation (Highhouse et al., 2009; Pires and Trez, 2018; Raithel and Schwaiger, 2015; Roberts and Dowling, 2002; Tischer and Hildebrandt, 2014). The company's reputation is a valuable asset because it reduces company uncertainty among stakeholders (Pfarrer et al., 2010; Wang et al., 2012) and increases the company's access to stakeholder resources (Chong and Halff, 2014). The importance of reputation for companies and stakeholders encourages more research on this topic. Barnett et al. (2006) stated that during the 2001-2003 period the number of articles about company reputation doubled from 2000 and five times compared to 1990-2000.

Signals of reputation to stakeholders about the company compared to other companies in similar industries (Iwu-Egwuonwu and Chibuike, 2011). A company's reputation has characteristics that are difficult to replicate and cannot be obtained quickly. A good reputation will be a valuable asset owned by the company (Gök and Özkaya, 2011; Shi, 2016). The role of the company grows in facing the competitive environment. Competitors are not easily neutralized because of difficulties in imitating and generally cannot be traded through market factors (Tischer and Hildebrandt, 2014). The company will be able to survive in the competition. This drives the company's reputation as a unique resource (Raithel and Schwaiger, 2015) and a source of sustainable excellence (Fombrun et al., 2000; Iwu-Egwuonwu and Chibuike, 2011).

The company runs its operations to get profits and maximize the welfare of their owners. Companies need funds to finance their activities. Sources of corporate funding can be obtained through loans from creditors (external funding) and owner's equity (internal funding) (Adenugba et al., 2016; Gitman and Zutter, 2012: 523). Companies that use loans in their capital structure are known as financial leverage.

Analysis of the impact of ownership structure on company reputation is still relevant because it influences stakeholder responses to the company (Delgado-García et al., 2010). Ownership structure in the perspective of origin / source of equity consists of domestic and foreign ownership (Mihai, 2014). Foreign ownership not only contributes to the growth of capital markets and the economies of developing countries but has become an important factor in the structure of corporate ownership (Ahmadjian and Robbin, 2005). In the Indonesian capital market, foreign ownership is quite dominant. PT Custodian Central Impact Indonesia registered $47 \%$ foreign shares and $52.7 \%$ local investors in August 2018 (Miftahudin, 2018).

Foreign ownership can bring a number of specific benefits for companies such as managerial skills and superior technology $(\mathrm{Ng}, 2016)$. Companies with foreign ownership can increase their productivity (Bircan, 2019). The presence of foreign technology transfer enables companies to operate more efficiently through the transfer of new knowledge in the production and distribution process. This will certainly enhance the company's reputation and be attractive to stakeholders, especially investors in investing their capital. Companies obtain valuable resources such as 
low capital costs, a larger customer base, reliable suppliers, and strategic business partners through foreign ownership (Peck-Ling et al., 2016).

Based on the background of the question, the question in this study is how the influence of Earning Persistence, Financial Leverage, Foreign Ownership toward Company Value mediated by Company Reputation. The purpose of this study was to determine how the influence of Earning Persistence, Financial Leverage, Foreign Ownership toward Company Value mediated by Company Reputation. This research is useful for investors, especially for making investment decisions in the capital market based on facts, data, and financial analysis that is appropriate with a rational approach to determine their investment returns.

\section{Literature Review}

\subsection{Earning Persistence, Reputation, and Company Value}

Salehi et al., (2018) examine whether future stock returns will reflect information about current earnings quality. Earnings quality is measured by accruals. Companies with high accruals show low-quality corporate profits, and vice versa. There are at least three possible explanations for why accruals predict stock returns, namely (1) conventional interpretations, high accruals indicate manipulation of earnings by managers, (2) accruals can be the main indicator of changes in the company's prospects, without manipulation by managers, and ( 3 ) accruals can also predict returns if the market views accruals as a reflection of past growth. Furthermore Lennox et al. (2016) says that a measure, accrual accounting, is the main indicator of earnings quality. Astami et al. (2017) described the differences in the company's accounting earnings and the underlying cash flow. Large positive accruals indicate that earnings are higher than the cash flow obtained by the company. This difference arises because of accounting conventions, and how much income and costs are recognized (the so-called "revenue recognition" and "matching" principles).

Overall good financial performance in the past will be a signal for all parties to believe that the company is of good quality. Perceptions of company quality are often associated with corporate reputation (Szöcs et al. 2016). Companies that have performed well in the past will have a bad reputation today (Shim and Yang, 2016). The impact of the company's financial performance in the past may affect the company's reputation in the future known as the term performance effect (Alwi et al., 2017). Ang and Wight (2009) in Flatt and Kowalczyk (2011) state that to build and maintain a reputation requires consistent and superior performance over competitors.

Companies with good financial performance in the past have encouraged investor confidence in the quality of the company. However, investors are not just looking at how much profit they make. Investors are more focused on profit that reflects their true performance and is likely to repeat in the future (persistently). Investors will look at companies with high profitability that will be able to face difficulties and have good prospects. This will boost investor confidence and increase the value of the company. Based on the above description, the following hypothesis is formulated:

H1a: Profitability has a positive effect on the reputation of the company.

H1b: Profitability has a positive effect on the company value.

\subsection{Financial Leverage, Reputation, and Company Value}

Companies that use loans in their capital structure are known as financial leverage. The use of loans causes the company to face financial risk (Adenugba et al., 2016). This risk creates the possibility of losses arising from failure to meet financial goals (Quayyoum et al., 2015). The use of loans causes the company to incur periodic burdens and repayments to shareholders become uncertain. Companies must bear the cost of repaying loans regardless of the income or sales of the product. Companies with high levels of financial leverage but are unable to generate sufficient interest before interest and taxes are sufficiently endangered because they cannot meet their interest pay obligations (Adenugba et al., 2016). Furthermore, the company increases the use of financial leverage and will incur higher borrowing costs as the lender is concerned with the ability to repay the company. Companies with financial problems will not attract the attention of stakeholders (García-Sánchez and Martínez-Ferrero (2016).

Companies that are unable to manage and use their loans well and are unable to cover the installment and interest payments, are therefore looking at high risk companies. The high risk has led investors to expect high rates of return. In addition, large or small corporate lending will make shareholder claims more risky than lenders so the cost of equity exceeds the cost of lending.

External shareholders like companies that are financially successful, yet they tend to avoid risk (Hart and Zingales, 2017). When two companies have the same financial performance, then the company with low risk will gain a better reputation (Ramos et al., 2018). Also, companies with higher financial leverage will have a lower reputation. This is 
due to the burden on the future that may impact the company's long-term and / or long-term survival (Gao et al., 2017).

Khan (2012) states that companies in Pakistan mostly use short-term loans and only a small number of companies use long-term loans. This is due to the high cost of long-term loans. The results show that short-term loans and total loans have a negative impact on the value of the company. Singh and Bansal (2016) also found a negative influence on corporate valuation in India measured using Tobin's Q. Based on the above description, the following hypothesis was formulated:

$\mathrm{H} 2 \mathrm{a}$ : Financial leverage has a negative effect on the reputation of the company.

$\mathrm{H} 2 \mathrm{~b}$ : Financial leverage has a negative effect on the value of the company.

\subsection{Foreign Ownership, Reputation, and Company Value}

An analysis of the ownership structure of a company's reputation is relevant because it influences the stakeholder response to the company. Ownership structure is one of the determinants of future corporate behavioral expectations (Brammer and Pavelin, 2006; Delgado-García et al., 2010). With information asymmetry, stakeholders use different information signals to generate expectations about the company's ability to meet their interests (Gomulya and Mishina, 2017).

One of the ownership structures that contribute to the capital and economic markets of developing countries and an important actor in corporate ownership structure is foreign ownership (Aguilera and Cladera, 2016). Foreign ownership has long-term investment horizons and focuses on potential growth prospects (Batten and Vo, 2015). Long-term foreign-oriented foreign investors have the capabilities and incentives to oversee the company (Jusoh, 2015). Choi et al. (2012) emphasize that the ownership of foreign shares and directors of foreign origin provides independent oversight of management. Management control through foreign investors will be related to improving the quality and value of the company.

Mishra (2014) found that there is an increase in corporate value in Australia when foreign investors have greater ownership allocation over market capitalization. Companies in Australia attract foreign investors who can boost their value because they signal the company's commitment to monitor actions that are in the best interests of the company. Greenway et al. (2014) show that foreign ownership has a U-shaped relationship with corporate performance in China. Company performance will increase as foreign ownership reaches $47-61 \%$ and then decline. Zechariah et al. (2014) state that high foreign ownership can help resolves crisis-related issues in terms of financial support, technology transfer, and experience.

Ownership structures serve as a signal to stakeholders that reflect company behavior or actions. Foreign ownership conducts long-term surveillance of actions that could harm the company. This can signal to other stakeholders that the company is monitoring from experienced investors. In addition, foreign ownership also brings technology transfer and managerial capabilities to the company's operations. The benefits of foreign ownership enhance the quality of the company in front of the stakeholders and attract investors to invest their capital.

H3a: Foreign ownership has a positive effect on the reputation of the company.

$\mathrm{H} 3 \mathrm{~b}$ : Foreign ownership has a positive effect on the value of the company.

\subsection{Company Reputation and Value}

The company is a collection of resources and these resources are an important aspect of the company's competitive position (Chiu and Chiou, 2016). Companies are expected to have sustained competitive advantage in order to compete in the industry. The RBV theory presented by Sehnem, et al. (2016) states that if a company has valuable (rare) and rare (rare) resources then it will have a competitive advantage. If the resources are also imperfectly imitable and there is no equivalent strategic resource (Non-substitutability) then the company will have sustained competitive advantage.

Corporate resources consist of tangible assets and intangible assets. Existing assets can be easily generated by competitors but non-existent assets are easily replicated and thus become important to the company (Osinski et al., 2017). Intangible assets play a role in determining the success of the company (Caliskan et al., 2011). One of the non-existent assets is the reputation of the company (Fernández-Gámez et al., 2015; Raithel and Schwaiger, 2015; Tischer and Hildebrandt, 2014).

Corporate reputation is a representation of the perception of the company's past actions and future prospects that reflects the overall attractiveness of the company to all its major constituents when compared to other leading competitors (Dowling, 2016). Good reputation is very important to a company because it has the potential for value 
creation. Companies take a long time to build their reputation (Delgado-García et al., 2011). In addition, companies also need consistent and superior performance from competitors to build their reputation (Flatt and Kowalczyk, 2011). Furthermore, Cao et al. (2012) state that companies that are already in good standing will try to protect their reputation because it is too expensive to rebuild. Long-term focus can hinder management from engaging in activities that negatively impact the company's reputation. This makes reputation as a valuable resource scarce, irreplaceable and irreplaceable.

Good corporate reputation shows that a company has intangible assets that are valuable, rare, difficult to emulate by other companies, and cannot be institutionalized. When a company has the resources to create sustainable competitive advantage, the company gains a superior return and increases the company's value. Based on the above description, the following hypothesis is formulated:

H4: Reputation has a positive effect on the value of the company.

\section{The conceptual framework}

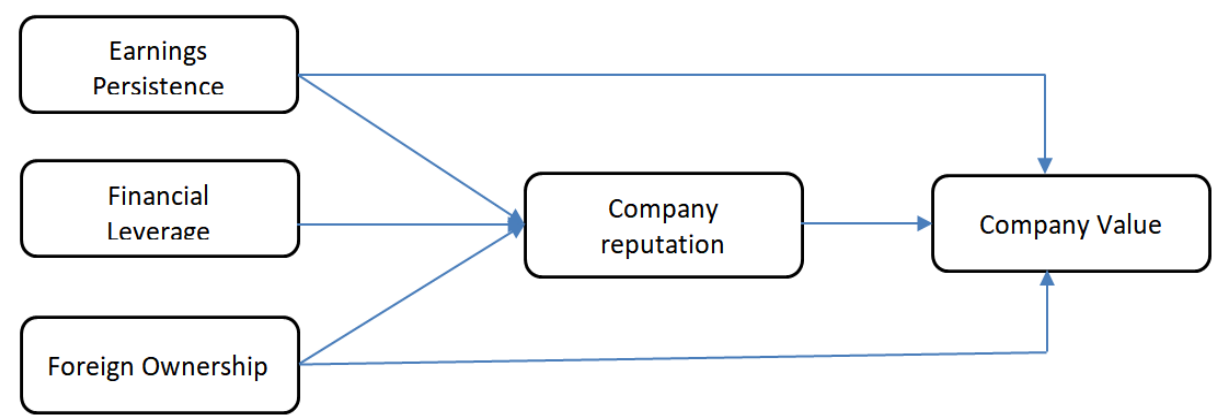

Figure 1. Research framework

\section{Research Methods}

This research empirically tests the influence of Earning Persistence, Financial Leverage, Foreign Ownership toward Company Value mediated by Company Reputation. The design of this study is hypothesis testing. Hypothesis testing will use previous theory or research or logic to test phenomena that exist. The hypothesis used is an explanatory or causal hypothesis. The variables used in this study are independent variables, intervening variables, and dependent variables. The independent variables used are profitability, financial leverage, and foreign ownership. The mediating variable used is the company's reputation. The dependent variable used is firm value.

The population in this study was all non-financial companies registered on the Indonesian Stock Exchange with a five-year observation period, which is from 2014 to 2018. The study did not focus on financial firms as they have different characteristics than non-financial companies (Du et al. 2017).

The sampling technique used in this research is a non-probability sampling technique with purposive sampling type. Purposive sampling is a technique for specifying samples with specific considerations (Sugiyono, 2012). The sample selection in this study is based on some of the criteria shown in Table 1 as follows:

Table 1. Number of samples

\begin{tabular}{lll}
\hline No & Criteria & Amount \\
\hline 1 & $\begin{array}{l}\text { Non-financial transactions registered on the Indonesian Stock } \\
\text { Exchange from 2014-2018. }\end{array}$ & 18 \\
\hline 2 & Companies issue financial statements in Rupiah currency. & 18 \\
\hline 3 & Companies using fiscal year December 31. & 12 \\
\hline 4 & Companies with complete data related to the variables in this study. & 12 \\
\hline
\end{tabular}

Source: Secondary data processed with SEM statistical analysis, 2019 


\section{Hypothesis testing}

Prior to hypothesis testing, bootstrap procedures were performed on sample data. Bootstrap was performed 300 times where in each bootstrap data was performed, resampling of 160 valid data was obtained. The bootstrap results with the bootstrap sample are 300 times assuming that the data has a normal distribution so that parameter testing in the model can be performed with t tests. The value of the structural model coefficient is considered significant if the count $>\mathrm{t}$-table is 1.96 (1.96 is the t-table value at $95 \%$ confidence level).

Hypothesis testing results for the external model concluded that all significant indicators were used to build the model whereas the hypothesis test results in the model can be seen in table 3 with results of all significant path coefficients.

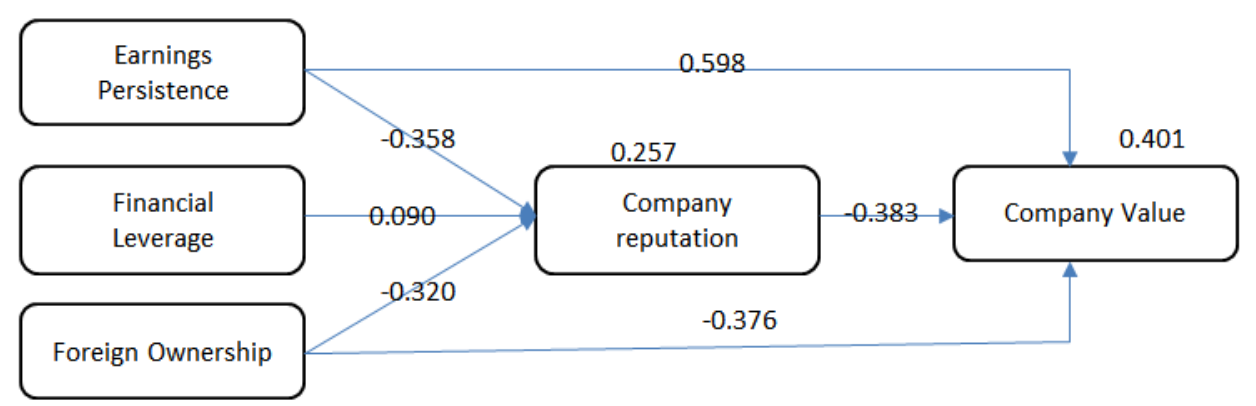

Figure 2. Test results using software smartpls

Based on the results of path analysis on Smartpls the direct influence of Earning Persistence on company reputation has a value of $-0,358$, Earning Persistence on company value has a value of 0.598 , the indirect effect of Earning Persistence on the value of the company through reputation has a value of 0.035 . Financial leverage on the company's reputation has a value of 0.090 . Foreign ownership of the company's reputation has a value of $-0,320$, Foreign ownership of the company value has a value of $-0,376$ and a reputation of the company has a value of $-0,383$

Table 3. T-value for path coefficients

\begin{tabular}{|c|c|c|c|c|c|c|}
\hline & $\begin{array}{l}\text { Original } \\
\text { Sample } \\
(\mathbf{O})\end{array}$ & $\begin{array}{l}\text { Sample } \\
\text { Mean (M) }\end{array}$ & $\begin{array}{l}\text { Standard } \\
\text { Deviation } \\
\text { (STDEV) } \\
\end{array}$ & $\begin{array}{l}\text { Standard } \\
\text { Error } \\
\text { (STERR) }\end{array}$ & $\begin{array}{l}\text { Tr Statistics } \\
(\mid \text { O/STERR } \mid)\end{array}$ & Description \\
\hline $\begin{array}{l}\text { Financial leverage } \\
\rightarrow \text { Company value }\end{array}$ & 0.597614 & 0.593277 & 0.074478 & 0.074478 & 0.024031 & $\begin{array}{l}\text { hypothesis } \\
\text { rejected }\end{array}$ \\
\hline $\begin{array}{l}\text { Financial leverage } \\
\rightarrow \quad \text { Company } \\
\text { reputation }\end{array}$ & 0.089944 & 0.104435 & 0.094189 & 0.094189 & 0.954937 & $\begin{array}{l}\text { hypothesis } \\
\text { rejected }\end{array}$ \\
\hline $\begin{array}{l}\text { Foreign ownership } \\
\rightarrow \quad \text { Company } \\
\text { reputation }\end{array}$ & -0.319731 & -0.309232 & 0.061297 & 0.061297 & 5.216081 & $\begin{array}{l}\text { hypothesis } \\
\text { accepted }\end{array}$ \\
\hline $\begin{array}{l}\text { Profitability } \\
\text { Company value }\end{array} \rightarrow$ & -0.375489 & -0.379649 & 0.072331 & 0.072331 & 5.191241 & $\begin{array}{l}\text { hypothesis } \\
\text { accepted }\end{array}$ \\
\hline $\begin{array}{l}\text { Profitability } \rightarrow \\
\text { Company } \\
\text { reputation }\end{array}$ & -0.355139 & -0.345648 & 0.089572 & 0.089572 & 3.964841 & $\begin{array}{l}\text { hypothesis } \\
\text { accepted }\end{array}$ \\
\hline $\begin{array}{l}\text { Company } \\
\text { reputation } \\
\text { Company value }\end{array} \rightarrow$ & -0.383295 & -0.380297 & 0.070315 & 0.070315 & 5.451098 & $\begin{array}{l}\text { hypothesis } \\
\text { accepted }\end{array}$ \\
\hline
\end{tabular}

Source: Secondary data processed with SEM statistical analysis, 2019 
Based on the above table, it can be seen that the Service Innovation and Financial leverage variables do not have a significant impact on the Company value with a $t$-value of $0.024<t$ table 1.96, the Financial leverage variable has no significant effect on the Company's reputation with the t-value of 0.954 <table 1.96, Foreign ownership variables had a significant effect on Company reputation with t-value 5.216>t-value 1.96, Variable Income Variation significantly influenced Company value with t-value 5.191>t-value 1.96,, Variable Income Variation had significant effect on Company reputation with t-value 3.964>t-value 1.96 , and the Company reputation variable significantly affects the Company value with a t-value of 5.451>t-value 1.96 .

\section{Discussion}

Based on the table above the Financial leverage variable does not have a significant effect on the Company value with a $\mathrm{t}$-value of $0.024<\mathrm{t}$ table 1.96. This is supported by Adenugba et al. (2016) emphasized that the previous year's financial performance as debt ratio had the highest coefficients and negatively impacted perceptions of corporate quality. External shareholders like companies that are financially successful, yet they tend to avoid risk (Henisz, 2017). When two companies have the same financial performance, then the company with low risk will gain a better reputation (Weng and Chen, 2017). Also, companies with higher financial leverage will have a lower reputation. This is due to the burden on the future that may impact the company's long-term and / or long-term survival (Khessina et al. 2018).

The Financial leverage variable had no significant effect on the Company's reputation with a $0.024<t$-table 1.96 . This is supported by Khan (2012) saying that companies in Pakistan mostly use short-term loans and only a small number of companies use long-term loans. This is due to the high cost of long-term loans. The results show that short-term loans and total loans have a negative impact on the value of the company. Singh and Bansal (2016) also found that negative leverage on corporate valuation in India was measured using Tobin's Q.

Foreign Ownership Variables have a significant impact on the Company's Reputation with a value of TV2 of 5.216>t-value 1.96. Some studies that examine the variables of ownership structure and corporate reputation include Ali et al. (2015); Delgado-García et al. (2010); Zhang and Schweitzer, (2019); and Noe et al. (2018). Ali et al. (2015) found that long-term institutional ownership has a positive effect on corporate reputation. Delgado-García et al. (2010) researched the effect of ownership structure on corporate reputation found that concentrated ownership of ownership reduced company reputation, insider ownership had a non-linear relationship to company reputation, and institutional ownership had a positive relationship with company reputation. Younas et al. (2017) found that the concentration of ownership positively affected the reputation of firms in Germany.

The Income-to-Variable Variable has a significant impact on the Company value with a t-value of 5.191>t-value 1.96. The results of a study conducted by Rahayu and Saifi, (2019) found that the stock return relationship with profit will be stronger for companies with higher profitability than companies with low profitability. Gaio and Raposo (2011) found a positive and significant relationship between profit quality and corporate value (Tobin's Q) by sampling companies from 38 countries over the period 1990 to 2003. This could indicate that companies with better profitability will rated higher by the stock market.

The Income Variation variable has a significant effect on the Company's reputation with a t-value of 3.964>t-value 1.96. The results of the study conducted by García-Sánchez and Martínez-Ferrero (2016) show that there is a positive impact on the quality of financial reporting and corporate reputation. Investors and other stakeholders positively evaluate companies that report better financial information. Martínez-Ferrero et al. (2016) found that companies that do not report real performance by doing profit management can impact investors, employees, customers, and the public that reflect their reputation and impact the company's market value.

The Company's reputation variable has a significant impact on the Company value with a t-value of 5.451>t-value 1.96. This is supported by Fernández-Gámez et al. (2015) found that corporate reputation as shown by reputation rating has a positive effect on market value. Tischer and Hildebrandt (2014) also find that investors who obtain information about a company's reputation rating will adjust its share price. Increased perceptions of the quality of the company enable the firm to capitalize on lower costs and increase investor attractiveness thus enhancing the company's stock market performance (Mazol and Mazol, (2018). The results of different studies by Gök and Özkaya H. (2011) found that portfolios in reputable enterprises in the emerging economy yield $10 \%$ lower than the overall market.

\section{Conclusion}

Based on the findings of the research and hypothesis testing previously proposed it can be concluded that Financial leverage variables have no significant effect on Company value, Financial leverage variables have no significant 
impact on Company reputation, Foreign ownership variables have significant influence on Company reputation, Variable Income Variability has significant impact on Company values, Income Variability variables have a significant impact on Company reputation and Company reputation variables have significant influence.

This research is only limited to non-financial companies listed on the Indonesia Stock Exchange with a five-year observation period, namely from 2014 to 2018 . And only limited to the effects of profitability, free cash flow, leverage, and foreign ownership on corporate value through corporate reputation.

This study has a shortcoming in the sampling technique used in this research is non-probability sampling technique with purposive sampling type. It should be noted that this method will result in a lack of external validity or a lack of generational capabilities in this study. The short observation year of research is only from 2014 to 2018.

For future researchers who are interested in researching the same title, seeing Adjusted R Square as this research is still low then researchers recommend for further research to add variables. Some of the independent variables recommended are: Free Cash Flow and Growth Opportunities, expand the sample and extend the year of observation, to obtain more generalizable results.

\section{References}

Acharya, V. V., \& Sabri Öncü, T. (2014). A proposal for the resolution of systemically important assets and liabilities: the case of the repo market. In The Social Value of the Financial Sector: Too Big to Fail or Just Too Big? (pp. 159-214).

Adams, M., Thornton, B., \& Sepehri, M. (2012). The impact of the pursuit of sustainability on the financial performance of the firm. Journal of Sustainability and Green Business, 1(1), 1-14.

Adenugba, A. A., Ige, A. A., \& Kesinro, O. R. (2016). Financial leverage and firms' value: a study of selected firms in Nigeria. European Journal of Research and Reflection in Management Sciences, 4(1).

Aguilera, R. V., \& Crespi-Cladera, R. (2016). Global corporate governance: On the relevance of firms' ownership structure. Journal of World Business, 51(1), 50-57.

Alwi, S. F. S., Ali, S. M., \& Nguyen, B. (2017). The importance of ethics in branding: mediating effects of ethical branding on company reputation and brand loyalty. Business Ethics Quarterly, 27(3), 393-422.

Astami, E. W., Rusmin, R., Hartadi, B., \& Evans, J. (2017). The role of audit quality and culture influence on earnings management in companies with excessive free cash flow. International Journal of Accounting \& Information Management.

Bircan, Ç. (2019). Ownership structure and productivity of multinationals. Journal of International Economics, 116, 125-143.

Chau, G., \& Gray, S. J. (2010). Family ownership, board independence and voluntary disclosure: Evidence from Hong Kong. Journal of International Accounting, Auditing and Taxation, 19(2), 93-109.

Chiu, M. C., \& Chiou, J. Y. (2016). Technical service platform planning based on a company's competitive advantage and future market trends: A case study of an IC foundry. Computers \& Industrial Engineering, 99, 503-517.

Dowling, G. R. (2016). Defining and measuring corporate reputations. European Management Review, 13(3), 207-223.

Du, J., Li, C., \& Wang, Y. (2017). A comparative study of shadow banking activities of non-financial firms in transition economies. China Economic Review, 46, S35-S49.

Gao, C., Zuzul, T., Jones, G., \& Khanna, T. (2017). Overcoming institutional voids: A reputation-based view of long-run survival. Strategic Management Journal, 38(11), 2147-2167.

Ginesti, G., Caldarelli, A., \& Zampella, A. (2018). Exploring the impact of intellectual capital on company reputation and performance. Journal of Intellectual Capital.

Gomulya, D., \& Mishina, Y. (2017). Signaler credibility, signal susceptibility, and relative reliance on signals: How stakeholders change their evaluative processes after violation of expectations and rehabilitative efforts. Academy of Management Journal, 60(2), 554-583.

Hart, O., \& Zingales, L. (2017). Companies should maximize shareholder welfare not market value. ECGI-Finance Working Paper, (521). 
Henisz, W. J. (2017). Corporate diplomacy: Building reputations and relationships with external stakeholders. Routledge.

Khessina, O. M., Goncalo, J. A., \& Krause, V. (2018). It's time to sober up: The direct costs, side effects and long-term consequences of creativity and innovation. Research in Organizational Behavior, 38, 107-135.

Lennox, C., Wu, X., \& Zhang, T. (2016). The effect of audit adjustments on earnings quality: Evidence from China. Journal of Accounting and Economics, 61(2-3), 545-562.

Mazol, A., \& Mazol, S. (2018). Does good corporate governance supports economic development: the role of CG in increasing stock market value, fighting corruption and attracting FDI.

Noe, T. H., Rebello, M. J., \& Rietz, T. (2018). Ownership Structure, Reputation Crises and Recovery: Theory and Experiment. Reputation Crises and Recovery: Theory and Experiment (June 25, 2018).

Osinski, M., Selig, P. M., Matos, F., \& Roman, D. J. (2017). Methods of evaluation of intangible assets and intellectual capital. Journal of Intellectual Capital.

Ponzi, L. J., Fombrun, C. J., \& Gardberg, N. A. (2011). RepTrak ${ }^{\mathrm{TM}}$ pulse: Conceptualizing and validating a short-form measure of corporate reputation. Corporate Reputation Review, 14(1), 15-35.

Rahayu, S. M., \& Saifi, M. (2019). The reciprocal relationship between profitability and capital structure and its impacts on the corporate values of manufacturing companies in Indonesia. International Journal of Productivity and Performance Management.

Ramos, M. I. G., Manzanares, M. J. D., \& Gómez, F. G. (2018). The effect of technological posture and corporate social responsibility on financial performance through corporate reputation. International Journal of Innovation: IJI Journal, 6(2), 164-179.

Salehi, M., Tagribi, M., \& Farhangdoust, S. (2018). The effect of reporting quality on stock returns of listed companies on the Tehran Stock Exchange. International Journal of Productivity and Performance Management.

Sehnem, S., Roman, D., Sehnem, A., \& Machado, N. S. (2016). Competitive advantage in a credit cooperative: the role of resources'. International Business Management, 10(15), 2768-2779.

Shim, K., \& Yang, S. U. (2016). The effect of bad reputation: The occurrence of crisis, corporate social responsibility, and perceptions of hypocrisy and attitudes toward a company. Public Relations Review, 42(1), 68-78.

Szöcs, I., Schlegelmilch, B. B., Rusch, T., \& Shamma, H. M. (2016). Linking cause assessment, corporate philanthropy, and corporate reputation. Journal of the Academy of Marketing Science, 44(3), 376-396.

Weng, P. S., \& Chen, W. Y. (2017). Doing good or choosing well? Corporate reputation, CEO reputation, and corporate financial performance. The North American Journal of Economics and Finance, 39, 223-240.

Younas, Z. I., Klein, C., \& Zwergel, B. (2017). The effects of ownership concentration on sustainability: A case of listed firms from USA, UK and Germany. Corporate Ownership \& Control, 14(3), 113-121.

Zhang, Y., \& Schweitzer, F. (2019). The interdependence of corporate reputation and ownership: a network approach to quantify reputation. Royal Society Open Science, 6(10), 190570. 